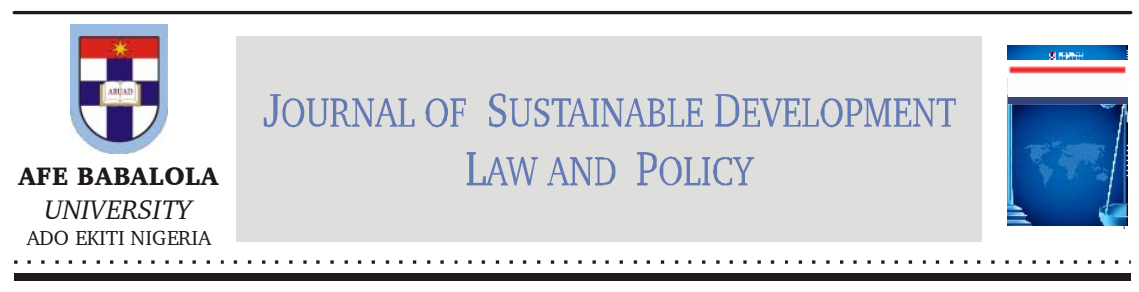

\title{
A CRITICAL APPRAISAL OF WOMEN'S REPRODUCTIVE RIGHTS IN NIGERIA
}

\section{Lilian Akhirome-Omonfuegbe*}

\begin{abstract}
This article examines the existing legal framework in Nigeria on reproductive health rights. It highlights how the dearth of women's reproductive rights laws in Nigeria continues to stifle the equal and adequate protection of women in family and larger societal contexts. The patriarchal nature of the Nigerian society, coupled with gaps in extant laws on women's rights, continue to deny women access to services, facilities and platforms which men have unfettered access to. Though studies abound in the area of human rights, the approach is usually purely empirical, medical or portraying a sociological point of view. By determining the highlighted issues, this article aims to postulate a model for the strengthening of the existing legal framework. This article suggests that enacting gender specific reproductive health laws in Nigeria, amending the provisions of the federal and state laws, including creating gender equality policies; and domesticating and implementing the already ratified international laws on gender equality and justice, could further advance the enforcement and protection of women's reproductive rights in Nigeria.
\end{abstract}

Keywords: Oil and Gas, Revenue, Law, Institutional Framework.

DOI: https://dx.doi.org/10.4314/jsdlp.v10i2.6

* LLB (Ekpoma), BL (Enugu), LLM (Wales), Lecturer, Faculty of Law Benson Idahosa University lakhirome@biu.edu.ng. 


\section{INTRODUCTION}

Reproductive rights of women have long been an important subject of discourse around the world, with some countries actively enacting laws that consolidate the rights of women to choose reproduction. Reproductive rights, as a term, was adopted in 1984 at the International Meeting on Women and Health in Amsterdam. Thus began the struggle to extend the scope of human rights to reproductive rights. ${ }^{1}$ In Nigeria, there is an existing body of laws, which indirectly protect these rights yet no specific framework has been adopted for the implementation, enforcement, and protection of these rights. $^{2}$

The International Conference on Population and Development (ICPD) held in Cairo, Egypt, in 1994 adopted a rights-based approach to sexual policies in relation to law, population, human rights, as well as sexual and reproductive health of women in general. ${ }^{3}$ The Conference adopted a Programme of Action by consensus, which emphasized the fundamental role of women's interests in population matters and introduced the concepts of sexual and reproductive health and reproductive rights. A new definition of population policy was advanced, giving prominence to reproductive health and the empowerment of women. ${ }^{4}$

Before this time, the enforcement and protection of women's reproductive rights had been the subject of continuous legislative and societal debate in many countries around the world. Reproductive rights refer to the rights of women to legal and safe abortion, right to quality healthcare, right to birth control, freedom from coerced sterilization and contraception, freedom from female genital mutilation, right to receive education about sexually transmitted disease and right to protection from sexual offences. ${ }^{5}$ It includes the right to plan one's family, freedom from interference in reproductive decision making and the right to be free from all forms of violence and discrimination which affect the

1 Oluwakemi Amuda Anyaleye, "Women and Reproductive Health Rights in Nigeria" Ontario Development Agency SSN 1923-6654.128 http:// www.ssrn.com/link/OIDA-Intl-Journal-Sustainable-Dev.html accessed 31 October 2019.

2 Ibid.

3 Ibid.

4 International Conference on Population and Development held in Cairo Egypt, 5 September - 13 September 1994 https://www.unfpa.org/events/internationalconference-population-and-development-icpd < accessed 31 October 2019>.

5 Anyaleye supra note 2 . 
reproductive life of a woman. ${ }^{6}$ It basically denotes the making of reproductive choices in an enabling environment and that people are protected from sexual or domestic violence, HIV \& AIDS, unsafe abortion, harmful traditional practices such as female genital mutilation (FGM) and maternal ill health. ${ }^{7}$

This article is divided into six sections. After this introduction, section 2 discusses reproductive health and rights, pointing out the links between the two concepts. Section 3 examines the existing legal framework for protection of reproductive rights in Nigeria. Section 4 discusses the gaps in enforcement and protection of reproductive rights in Nigeria as well as the inadequacies and impediments to implementation of the existent laws. Section 5 provides recommendations to engender the protection and enforcement of reproductive rights in Nigeria, which include the need for specific legislations and amendment of existing laws as well as the way forward for gender specific rights in Nigeria. Finally, section 6 sets out the conclusion.

\section{THE CONCEPT AND SCOPE OF REPRODUCTIVE HEALTH AND RIGHTS}

Over the past decades, scholars have begun to advocate on the importance of incorporating gender-specific human rights protection into national law and legal systems. ${ }^{8}$ Reproductive rights are closely linked but not limited to health rights.

\subsection{Reproductive Health}

The concept of reproductive health arose out of the need for a holistic response to the fragmentation of healthcare services available to deal with human sexuality and reproductive issues. ${ }^{9}$ In the past, reproductive health had been approached as a purely medical concern rather than the broad perspective that it actually encompassed. It first gained global attention at the United Nations International Conference on Population

6 Ibid.

7 Nkolika Ijeoma Aniekwu. Reproductive Health Law; A Jurisprudential Analysis of Gender Specific Human Rights for the African Region1st edn( Ambik Press Nigeria. 2011).

8 Ibid.

9 Ibid. 
and Development (ICPD) at Cairo, Egypt, in $1994 .{ }^{10}$ Subsequent platforms like the 1995 Fourth World Conference on Women (Beijing Platform), have further globalized the concept of reproductive health and contributed to the discourse on the topic.

There is no universal definition of reproductive health. According to the ICPD, reproductive health is:

A state of complete physical, mental and social wellbeing, not merely the absence of disease or infirmity, in all matters relating to the reproductive system and to its functions and processes. The right to reproductive health implies that people have a satisfying and safe sex life and that they have the capacity to reproduce and the freedom to decide if, when and how to reproduce and how often to do so. Implicit in this last condition is the right of men and women to be informed and to have access to safe, effective, affordable and acceptable methods of their choice, as well as other methods for regulation of fertility which are not against the law, and right of access to appropriate health care services that will enable women to go safely through pregnancy and childbirth and provide couples with the best chances of having a healthy infant. ${ }^{11}$

From this definition we can deduce that reproductive health covers both the physical and mental state of men and women in relation to their sexuality and its consequences and the exercise of their rights therein. The World Health Organization (WHO) has defined health as "a state of complete physical, mental and social well-being and not merely the absence of disease or infirmity." 12

Reproductive health encompasses the entirety of the human existence and needs. It centres on developments from the "womb to the tomb". There exists just one reproductive right, whereas there are numerous human rights in existence, which invariably all have positive implications for the protection of reproductive rights. ${ }^{13}$ Reproductive rights embrace the rights of men and women to be informed and have access to safe, effective, affordable, and acceptable methods of family planning of their choice as well as other legal methods of regulating fertility. It also includes

10 Ibid.

11 Par 7.2 of ICPD Programme of Action.

12 Preamble to the Constitution of World Health Organization 1946.

13 Anyaleye, supra note 2. 
the right to appropriate health care services and facilities to help women go safely through pregnancy and childbirth. It is a constellation of methods, techniques and services that contribute to reproductive health and well-being by preventing and solving reproductive health problems. ${ }^{14}$ Thus reproductive health entails a paradigm shift from the traditional scope of maternal and child health and family planning to a broader and more comprehensive scope, which covers a range of services like family planning, counselling, information, education, communication, antenatal services, safe delivery, postnatal care, infant and women's healthcare, prevention and treatment of infertility, prevention and treatment of infections, sexually transmitted diseases (including management of HIV \& AIDS), breast cancer, cancer of the reproductive system (for example ovarian cancer) and other reproductive conditions, as well as active discouragement of harmful cultural practices like female genital mutilation. ${ }^{15}$

The definition of reproductive health offers a comprehensive and integrated approach to health needs related to reproduction. It puts gender at the centre of reproductive health care and recognizes, respects, and responds to the needs of women in particular. ${ }^{16}$ The impact of reproductive health is not limited to the individual, family or society; it extends beyond national boundaries to the global community. Reproductive health has become of increasing concern as a lack of understanding or non-recognition of it, especially in developing countries, affects the health and well-being of the people directly concerned, in this case, women.

\subsection{Reproductive Rights}

The control of women's reproductive and sexual capacities dates back in time. Over the years, customs and traditions dictated these capacities. Subsequently, governments apply criminal laws as an instrument to control morality, for instance through the prohibition of birth control and abortion or by penalizing unacceptable forms of sexual behaviour. Global awareness has increased in relation to the protection and promotion of reproductive rights, given the impact of the ICPD and the Beijing platforms. The two conferences projected the recognition and

14 Ibid.

15 Ibid.

16 Aniekwu, supra note 8, p. 15. 
protection of reproductive rights to the global stage, increasing awareness that such matters are now matters of social justice, which can be addressed through improved application of human rights provisions already contained in extant national laws, as well as regional, and international human rights treaties. ${ }^{17}$

The ICPD points out that reproductive rights represent some human rights already recognized in national law, International Human Rights and other United Nations documents. These rights are hinged on the recognition of the rights of individuals or couples to freely decide the number, spacing and timing of their children and to access information on safe means to do so. In exercising these rights, they should take into consideration their needs and responsibilities at the same time keeping in consideration their future children. ${ }^{18}$

Reproductive rights are closely linked but not limited to health rights. Erhun states that reproductive rights encompass the right to reproductive healthcare, which includes the right to regular access to safe, highquality, reproductive healthcare services and the right to reproductive self-determination. This includes the right to plan one's family, freedom from interference in reproductive decision making and the right to be free from all forms of violence and discrimination, which affect the reproductive life of a woman. In addition to health, reproductive rights promote the autonomy, choice and freedom in matters of reproduction. ${ }^{19}$

Reproductive health rights, therefore, imply the right of couples to decide freely and responsibly on the number, timing and spacing of their children and have the information, education and means to do so; attain the highest standards of reproductive health and make decisions about reproduction free of discrimination, coercion and violence.$^{20}$ Reproductive rights guarantee reproductive health. Women's reproductive health is guaranteed largely by existing rights, which in turn are determined by the legal enforcement and protection of same. Reproductive rights recognizes that a woman should be able to defend her right over her

17 Ibid.

18 Para 7.3 ICPD Programme of Action.

19 Mercy Erhun "A Legal Framework for the Enhancement of Women's Reproductive Health as a Means of Attaining Sustainable Development in Nigeria", Journal of Law, Policy and Globalization, Vol.40, 2015, Faculty of Law, Obafemi Awolowo University, Ile-Ife, Nigeria.

20 Ogugualkpeze "Customary Perspective on Reproductive Health Rights" Journal of Health Law and Reproductive Rights (JHLRR) Issue 4-5 , 2013-2014, p. 57. 
body and personal choices concerning her body - reproductive options are an integral part of this right.

It may thus be inferred that the definition of reproductive rights arrived at by the Beijing Platform Action has been derived from broadly established rights. Reproductive rights are concerned with reproduction, as stipulated in National Laws, and other documents such as reports from International Human Rights Institutions; and must therefore be respected and enforced by State parties. These rights include inter alia:

i. The rights of all couples and individuals to decide freely and responsibly the number and spacing of their children with accessible and available means of contraception;

ii. The right to have information, education and the means to do so;

iii. The right to safe abortion under specific circumstances and conditions;

iv. The right to be free from violence;

v. The right to be protected from HIV \& AIDS and other sexually transmitted diseases affecting the sexual reproductive health of individuals;

vi. The right to safe motherhood. ${ }^{21}$

The protection of reproductive rights has evolved such that some countries now have laws and state policies addressing the abuse of such rights and providing remedies where necessary. ${ }^{22}$

\section{EXISTING LEGAL FRAMEWORK ON PROTECTION OF REPRODUCTIVE RIGHTS IN NIGERIA}

Nigeria has a plethora of domestic laws providing for the protection of reproductive health rights within the legal system. Some of these laws, although not directly touching on reproductive rights, rather protect rights generally, which invariably leads to protection of reproductive rights. This alludes to the willingness of the government to protect these rights while giving citizens access to healthy reproductive lives and

21 Cited in Nkolika Ijeoma Aniekwu. Reproductive Health Law; A Jurisprudential Analysis of Gender Specific Human Rights for the African Region1st edn (Ambik Press Nigeria. 2011), p. 19.

22 See Argentina, Mexico, Colombia. 
catering to their well-being. These laws are discussed in the subsequent sub-sections.

\subsection{The Constitution of the Federal Republic of Nigeria 1999 (as amended)}

Chapter 4 of the Constitution provides for the protection of human rights generally. It, however, does not voice out gender-specific protection (in this case women's reproductive rights). Nevertheless, some of the rights protected under the Constitution can also be extended to include the protection of reproductive rights.

Section 14 (2) provides that the security and welfare of the people shall be the primary purpose of government. This is in consonance with the scope of reproductive health, which includes "a state of complete physical, mental and social well-being". Thus, catering to the reproductive well-being of individuals is imbedded in their security and welfare. Furthermore, although unenforceable, section 17 under the social objectives and directives policies, ${ }^{23}$ stipulates that the government is obligated to direct its policies towards ensuring adequate medical and health facilities for all. This also resonates with the scope of reproductive health and rights covering access to acceptable, affordable and safe methods of regulating fertility and right to access appropriate medical services. It further provides that children, young persons and the aged shall be protected against exploitation and against moral or material neglect. ${ }^{24}$ The section goes on to encourage the evolution and promotion of family life. ${ }^{25}$ In sub-section 3 we see the provision that the working conditions should be just and humane and there should be adequate facilities for leisure, social, religious and cultural life. This provision, if properly harnessed, will cater to the reproductive health and rights needs of working class mothers.

Similarly, section 33 of the Constitution provides that:

Every person has a right to life and no one shall be deprived intentionally of his life, save in execution of a court sentence in respect of a criminal offence of which he has been found guilty in Nigeria.

23 Section 6 of the Constitution makes this provision non-justiciable and thus unenforceable in court.

24 Constitution of the Federal Republic of Nigeria 1999 (as amended) section 17(f).

25 Ibid, para (h). 
The rights to good healthcare, amenities, safe motherhood, etc., are all essential for protecting the right to life. Access to information and education on preventable diseases that can shorten the life span of women and children is essential in protecting this right to life. Thus, governments all over the world are tasked with the responsibility of protecting the right to life by taking positive steps to provide adequate health facilities, especially for women and children.

Section 34 of the Constitution provides that no person shall be subjected to torture or inhuman or degrading treatment; no person shall be held in slavery or servitude and be required to perform forced or compulsory labour. Torture has been defined to include mental harassment and physical brutalization while inhumane treatment characterizes any act without feelings for the sufferings of the other. ${ }^{26}$ Thus stigmatization of women living with HIV \& AIDS, the practice of ostracizing young girls with VVF in rural areas all amount to breach of their rights to dignity of the human person, which is in fact an infringement of their reproductive health rights.

Section 35 provides for the right to personal liberty and that no person should be deprived of their personal liberty under any circumstances. The liberty of persons living with HIV \& AIDS should not be interfered with; even if it is for the purpose of treatment, there should be consent before quarantining such persons. Though it can be argued that in cases where it becomes necessary to protect the greater population from contracting communicable diseases, nonetheless this can be facilitated through counselling and information. The infected person is entitled to proper guidance and counselling in order to understand the necessity for the isolation. There should be respect for the infected person's right to integrity and respect for their personal space, and no one should be tested without being informed of the intention to do so - testing should be voluntarily submitted to. All these are essential in the protection of reproductive health rights.

Section 37 provides for the right to private and family life. This provision covers the protection of the privacy of citizens, their homes, correspondence, telephone conversations and telegraphic communications. As noted earlier in this work, reproductive health implies that people should be able to have satisfying, safe, and free sexual life that is

26 See the Court of Appeal in Uzoukwu v Ezeonu (1991) 6 NWLR, Pt 200, 708, 764-778. 
not impeded by custom or gender. Reproductive health rights, therefore, imply that couples can decide freely and responsibly on the number, timing, and spacing of their children and have the information, education and means to do so, attain the highest standards of reproductive health and make decisions about reproduction free of discrimination, coercion, and violence. ${ }^{27}$

This right allows a woman to procure information discreetly on her reproductive life, enhance her sexual life without fear of her private sexual activities being posted online or put in the public domain without her consent, as a means to shame her. The right to privacy involves obligation to respect physical privacy, including the obligation to seek informed consent to HIV testing and to safeguard privacy of information, including the need to respect the confidentiality of all information relating to a person's HIV status. The individual's interest in their privacy is particularly compelling in the context of HIV \& AIDS, firstly, in view of the invasive character of a mandatory HIV testing and, secondly, by reason of the stigma and discrimination attached to the loss of privacy and confidentiality if HIV status is disclosed. The community has an interest in maintaining privacy, so that people will feel safe and comfortable in using public health measures, such as HIV \& AIDS prevention and treatment services.

The right to privacy, and family life, also includes the right to marry, and to have a family in a protected manner. Therefore, the right of people living with HIV \& AIDS is infringed upon by mandatory pre-marital testing, and/or the requirement of AIDS-free certificate, as a precondition for the grant of a marriage license by the church. Secondly, forced abortions or sterilization of HIV infected women violates the human rights of a family, as well as the right to liberty, and integrity of the person. Women should be provided with accurate information about the risk of prenatal transmission to support them in making voluntary informed choice about reproduction. Also measures to ensure the equal rights of women within the family are necessary to enable them negotiate safe sex with their husbands/partners. ${ }^{28}$

27 Ogugua Ikpeze, "Customary Perspective on Reproductive Health Rights" (2014) 4-5 Journal of Health Law and Reproductive Rights 57.

28 Muhammed Tawfiq Ladan. "Review of Existing Reproductive Health Policies and Legislations in Nigeria" (A Paper Presented at a One - Day Stakeholders' Forum On Reproductive Health In Nigeria) http://www.gamji.com/article5000/ NEWS5997.htm accessed 12th July 2019. 
Section 38 provides that:

Every person shall be entitled to freedom of thought, conscience and religion, including freedom to change his religion or belief: This provision protects the rights of a woman to safe abortion where necessary and her choices should not be questioned on the basis of societal or general beliefs. It can also be implied to protect women who choose to reproduce through IVF, or women who choose to freeze their eggs for future use for reproduction when they find a sperm donor such choices should not be frowned [upon] simply because they do not align with the general opinions.

Sections 39-40 provides for the right to freedom of expression and right to freedom of assembly. These rights include the right to seek, receive, and disseminate information on any area of a woman's reproductive health and well-being. It also implies the right to form peaceful groups to share information and educate each other, so as to make informed choices concerning their reproductive health. They have a right to peaceful rallies to demand changes from government as well as enforce their rights.

Section 42(1) of the Constitution provides for freedom from discrimination. It is trite that discrimination is one of the major setbacks to the protection and enforcement of reproductive rights in Nigeria. The patriarchal nature of the society discriminates against women simply because they are women and, hence, denied access to some platforms, which men have unfettered access to. There are also cases of unequal pay, and unequal working standards between men and women in organizations. ${ }^{29}$

Furthermore, discrimination can occur in specific ways for women living with HIV \& AIDS in rural communities, such as denial of access to medical care. Some of the women living with HIV \& AIDS are uneducated, poor and living with violent men who deny them access to healthcare. All of these amount to discrimination and a breach of their reproductive health rights.

29 Damilola Olawuyi and Idowu Ajibade "Climate Change Impacts on Housing and Property Rights in Nigeria and Panama: Toward a Rights-Based Approach to Adaptation and Mitigation", in: Dominic Stucker and Elena Lopez-Gunn (eds.) Adaptation to Climate Change through Water Resources Management: Capacity, Equity and Sustainability (New York: Routledge 2014) 264-284. 
Section 41 provides for the right to freedom of movement. Every citizen is entitled to move freely within Nigeria and to reside in any part of the country. Any religious or cultural practice that restricts or constrains a woman's right of movement is a direct infringement of her rights.

\subsection{The Administration of Criminal Justice Act (ACJA) 2015}

The ACJA came into being in May 2015; it has 495 sections and is divided into 49 parts. The ACJA merges the main provisions of the two principal legislations, CPA and CPC, into one principal federal Act, which is intended to apply uniformly in all federal courts across the entire Federation. It provides a uniform system for criminal justice administration in both Northern and Southern Nigeria today. It is imperative that it is adopted by all states in the federation.

What makes the ACJA stand out are the gender-specific provisions as well as its promotion of the enforcement and protection of reproductive health and rights. It also makes provisions for the protection of children where the need arises. Section 9(3) provides that the search of a woman shall be made decently and by another woman unless it is practically impossible for the search to be carried out by a person of the same sex. This exceptional situation where a search by a person of same sex is impossible is lacking in the CPC and CPA. This provision re-enforces the respect of a woman's right to dignity and leaves no room for indecent harassment, which could occur whereby a woman is being searched by a male officer.

Section 12 provides that where a suspect enters a house or place in the actual occupancy of a woman who by custom or religious practice does not appear in public, the person making the arrest shall: before entering the house give notice to the woman that she is at liberty to withdraw: and afford the opportunity and facility for withdrawing, but the notice shall not be necessary where the person making the arrest is a woman.

Implicit in this provision is a woman's right to private and family life. This protects the privacy of citizens, their homes, as they should not be barged in on by the police, under the guise of carrying out arrest or other official duties. Section 191 ACJA provides that:

a woman who has contracted a valid marriage shall have in her own name against all persons including the husband of the marriage, the same remedies and redress by way of criminal 
proceedings for the protection and security of her person or her own separate property as if such property belonged to her as an unmarried woman.

The implication of this provision is that a married woman who is in an abusive relationship will be able to enforce her ownership over property and thus economic deprivation (which makes many women remain in abusive relationships), will not deprive her from fleeing such an abusive relationship. This provision will also protect women in situations where the customary widowhood practice of the diseased man's relative taking all his property from his widow, prevails.

Section 404 provides that the sentence of death in the case of a pregnant woman will be suspended until the baby is delivered and weaned. This impliedly includes the right of access to appropriate health care services that will enable such a woman to go safely through the pregnancy till childbirth and provide her with the best chances of having a healthy infant.

Section 415 (1- 4) outlines the protocols to be followed where a woman convicted of a capital offence is alleged to be pregnant or who subsequently becomes pregnant. The court shall, before sentence is passed, determine the question of whether or not she is pregnant.

Section 466 of the Act further makes provision that the supervising officer in respect of female convict shall be a female. This also further protects the woman's right to dignity and protects her privacy when necessary.

Section 319 and Section 321 provide that a court can order a defendant to pay compensation to the victim. It goes further to provide that after conviction, irrespective of the sentence given, the court can order that restitution be made or compensation be paid to the victim or his estate. This impliedly includes payment of hospital bills, fees for counselling and restitution of rape or abuse victims.

The ACJA has clearly made laudable contributions through its reinforcement of the rights of women as contained in the Constitution of the Federal Republic of Nigeria 1999 (as amended) and even the United Nations Convention on the Elimination of All Forms of Discrimination against Women (CEDAW). Many of these provisions were lacking in the previous Criminal Procedure Act and Criminal Procedure Code, which regulated the administration of criminal justice in Nigeria. Being a federal law, it is necessary for states to domesticate the ACJA to drive its impact home. Some states in Nigeria have already taken the step to domesticate 
the act. Examples include Edo State, Lagos State, Enugu State, Ekiti State.

\subsection{Violence against Persons Prohibition (VAPP) Act $\mathbf{2 0 1 5}^{30}$}

This VAPP Act prohibits all forms of violence against persons in public and private life and provides maximum protection and remedies for victims as well as punishment for offenders. Section 1 defines rape as:

the intentional penetration of the vagina, anus or mouth of another person with any other part of his or her body or anything else without consent or consent is obtained by force or by means of intimidation of any kind or by fear of harm or by means of false and fraudulent representation as to the nature of the act or the use of any substance or additive capable of taking way the will of such person.

The Act provides a punitive measure of life imprisonment (various other imprisonments) for anyone found guilty of this offence under the Act. It further provides for an offence known as spousal battery, ${ }^{31}$ which is the intentional and unlawful use of force or violence on a person, unlawfully touching, beating or striking of another person against his or her will with the intention of causing bodily harm. Once the guilt is established, the offence is punishable with three years' imprisonment or fine of N200,000.

The Act further prohibits the offence of forceful ejection from home; ${ }^{32}$ deprivation of liberty (psychological violence), ${ }^{33}$ forced financial dependence or economic abuse; ${ }^{34}$ forced isolation; ${ }^{35}$ and emotional, psychological and verbal violence. ${ }^{36}$ Furthermore, the Act prohibits harmful traditional practices. All traditional behaviour, attitudes or practices, which negatively affect the fundamental rights of women, girls, or any person and includes harmful widowhood practices, denial of

30 The Violence against Persons (Prohibition) Act (hereinafter known as "the VAPP Act") came into force on 25 May 2015.

31 Ibid, s. 19.

32 Ibid., s. 9.

33 Ibid., s. 10.

34 Ibid, s. 17.

35 Ibid, s. 13.

36 Ibid, s. 14. 
inheritance or succession rights, female genital mutilation, forced marriage, forced isolation are regarded as offences punishable with four years' imprisonment or N500,000.00 fine or both.

\subsection{Labour Law $^{37}$}

Section 54 (1) of the Labour Act, in protecting pregnant working women, provides that in any private industrial or commercial or any agricultural undertaking or in any branch thereof, a woman:

i. Shall have the right to leave her work if she produces a medical certificate given by a registered medical practitioner that her confinement will probably take place within six weeks.

ii. Shall not be permitted to work during the six weeks following her confinement.

iii. If she is absent from work pursuant to paragraph (a) or (b) of this subsection and been continuously employed by her employer for a period of six months or more immediately prior to her absence, shall be paid not less than 50 per cent of the wages she would have earned if she had not been absent; and

iv. Shall in any case, if she is nursing her child, be allowed half an hour twice a day during her working hours for that purpose.

Section 54 (2) further provides that subsections (1) and (2) shall have effect notwithstanding any law relating to the fixing and payment of minimum wage. These provisions all the way to subsection (5) are relevant to women's reproductive rights by balancing the interest of the pregnant woman, motherhood and child survival as against the interest of the employers. ${ }^{38}$ This also resonates with the right of the woman to safe motherhood. The provisions of subsections (2) and (3) entitle the woman to at least 12 weeks maternity leave. In more recent practice, however, few women take the leave as ordered by the provisions. Instead, they take the 12 weeks post-natal leave. The practice is now given official approval by virtue of a written policy emanating from Ministry of Establishments of Labour and Productivity.

37 Labour Act Cap 198 LFN 1990.

38 Olawunmi Baiyewunmi and Aihinoria Odoh, "Are There Any indications of Capacity or Prospects and Opportunities for Reproductive Rights Protection within the Nigerian Legal System?" (Seminar Paper on Reproductive Health Law, Presented at the University of Benin 2014). 
Arguably, there are two mutually reinforcing reasons for this development in practice. The position of the law appears to have been advised on medical knowledge about both pregnancy-advised and pregnancy-induced slow-down of the woman as she approaches delivery. However, it appears that in recent times, there are strong, differing views within medical circles of how much slow-down is required by pregnant women generally and by individual pregnant women so that the adoption of a protective legislative mandate is necessitated. Consequently, as many women get the clean bill of health from their doctors to carry on with work, they feel less inclined to use the six weeks leave prior. They feel more inclined/compelled to accumulate the 12 weeks for post-natal maternity leave because they regard the legally reserved six weeks as highly inadequate. The recent child survival campaigns, which advocate exclusive breastfeeding for the child for six months reinforce the position that the six weeks post-natal maternity leave legally reserved is inadequate and incapable of providing legislative support to the campaign. ${ }^{39}$

However, it is unfortunate that many women employed by private business do not enjoy these rights. These provisions also protect a woman from job termination where she takes ill during the pregnancy and has to take a leave of absence from work. It is worthy to note that section 54(5) provides that the child referred to in the section includes both legitimate and illegitimate - thus an employer cannot deprive a woman of maternity leave solely on the ground that she is unmarried and is going to be a single mother. This type of discrimination of children born out of wedlock comes within the purview of what is forbidden under the Constitution of Nigeria, ${ }^{40}$ that no person should be discriminated against solely on grounds of the circumstances surrounding his birth.

In spite of this we have internal legislations that still foster discrimination, for instance the Police Act provides that an unmarried woman who becomes pregnant shall be discharged from the force and shall not be re-listed save with the approval of the Inspector General. ${ }^{41}$ Not only is this clearly discriminatory, it is a clear violation of a woman's right to freedom of thought and conscience as well as a violation her right to private family life.

39 Muhammed Tawfiq Ladan "Review Of Existing Reproductive Health Policies and Legislations in Nigeria" (A Paper Presented at a One - Day Stakeholders' Forum on Reproductive Health In Nigeria) http://www.gamji.com/article5000/ NEWS5997.htm < accessed 12 July 2019>.

40 s 42 (2).

41 Regulation 127 Police Act Cap 1990 LFN. 


\subsection{The Trafficking in Persons (Prohibition) Law Enforcement and Administration Act 2003}

This Act prohibits and prescribes punishment for trafficking in persons particularly women and children - and establishes an agency, The National Agency for the Prohibition of Trafficking in Persons (NAPTIP), charged with the responsibility of investigating and prosecuting offenders as well as counselling and rehabilitating trafficked victims.

\subsection{International Law}

Nigeria is party to several international instruments that guarantee reproductive rights. These include the African Charter on Human and Peoples Rights, the Additional Protocol on Women's Right to the African Charter 2003, and the Convention on the Elimination of All Forms of Discrimination against Women.

\subsubsection{The African Charter on Human and Peoples Rights}

The African Charter on Human and Peoples Rights was adopted at the 18th Conference of Heads of States and Governments of Organization of African Union in Banjul in July 1981. It has long been domesticated and made part of Nigerian Laws (see the case of Gani Fawehinmi v Abacha). ${ }^{42}$ It was incorporated as The African Charter on Human and Peoples Right (Ratification and Enforcement) Act, Cap 10 LFN 2004. This chapter addresses gender issues and prohibits gender discrimination.

\subsubsection{The Additional Protocol on Women's Right to The African Charter 2003}

This was adopted by the African Union in Maputo, Mozambique. It is a key instrument in the advancement of reproductive and sexual health. It was a direct response to women's needs and sets out specific standards and measures for the recognition and protection of women's rights. It also contains provisions on the elimination of harmful traditional practices. ${ }^{43}$

42 (1996) 9 NWLR (pt 475) 710.

43 Nkolika Ijeoma Aniekwu Reproductive Health Law; A Jurisprudential Analysis of Gender Specific Human Rights for the African Region1st edn (Ambik Press Nigeria, 2011), p. 101. 
Article 5 provides for elimination of harmful traditional practices against women. Article 14 specifically provides for the health and reproductive rights of women. Articles 20 and 21 provide for the protection of widows' rights. However, it is yet to be domesticated by Nigeria. Nevertheless, it is binding on all states that have ratified it. It was applied in the case of Dorothy Njemanze \& three others $v$. Federal Republic of Nigeria. ${ }^{44}$ It was a case of gender-based violence against four women in Nigeria by the agents of the Nigerian government. Judgment was given in favour of the plaintiffs. This is significant because it is the first ever pronouncement of a regional court of law on women's human rights based on the provisions of the Maputo Protocol.

\subsubsection{The Convention on the Elimination of All Forms of Discrimination against Women}

This Convention was signed by Nigeria in 1985 and ratified without reservations; yet it has not been domesticated as required by Section 12 of the Constitution. Thus, it does not form part of our municipal laws. This is unfortunate, considering that the Convention on the Elimination of all forms of Discrimination against Women (CEDAW) is a genderspecific instrument. The Convention is the only international instrument that takes the understanding of human rights from being gender neutral or gender blind to being women focused, recognizing the specific and differential needs of women on the basis of biology and gender or social construction. The Convention brings about a convergence between an international treaty with women's law leading to equality and justice for women. It demands not only the prohibition of discrimination against women but also places positive obligations on the State for the fulfilment of women's right to equality. It requires measures that will help women overcome the residual impact of past or historic discrimination against women. It is, therefore, not only about eliminating individual acts of discrimination but also about taking insightful initiatives to transform institutional practices to respect, protect and fulfil women's equality rights. ${ }^{45}$

44 Suit No: ECW/CJ/APP/17/14.

45 Shanthi Dairiam "International Norms and the Realization of Women's Human Rights: The Role of Civil Society Organizations" https://www2.ohchr.org/ english/bodies/cedaw/docs/CEDAW30thAnniversaryEvent_ShantiDariam_ E.pdf < accessed on 12 July 2019>. 
In addition to the foregoing national laws, several states in Nigeria have gone ahead to enact specific laws protecting women's health. These are indicative of the willingness and commitment on the part of Government to protect women's reproductive health and rights. ${ }^{46}$ The next section discusses the key gaps and impediments that continue to stifle the realization, protection and fulfilment of women's reproductive rights in Nigeria.

\section{IMPEDIMENTS TO ENFORCEMENT OF REPRODUCTIVE RIGHTS IN NIGERIA}

Legislations and policies are in place to protect reproductive health in Nigeria, but it is undeniable that there is a gap between extant laws and their implementation. Recognizing one's rights is one thing; enforcing it is another. In this milieu, knowledge of one's rights is complicated by a lack of understanding of how to demand for them. In the past decades, scholars have clamoured for the incorporation of gender-specific policies in our laws. The setbacks encountered on this journey are due largely to the inability of society to understand that reproductive rights indeed need to be protected.

Tradition and cultural practices no doubt contribute to existing impediments in enforcement of these rights. Discussion of reproductive and sexual health rights, which had hitherto been a "taboo" in traditional African societies, is now on the increase among African scholars. While the right to health has been an internationally recognized human right, reproductive health rights gained formal acceptance only in $1993 .{ }^{47}$

46 Some of these include Prohibition of Infringement of a Widow's and Widower's Fundamental Human Rights Law No. 3, 2001, Enugu, The Female Circumcision and Genital Mutilation(Prohibition) Law of Ogun State 2000, Malpractices against Widows and Widowers (Prohibition) Law 2004 Anambra State, Law on Female Genital Mutilation (Prohibition) 1999 Edo State, Inhuman Treatment of Widows (Prohibition) Law 2004 Edo State, Abolition of harmful Traditional Practices against Women and Children 2000, Ebonyi State, Gender and Equal Opportunities Law No. 7 of 2007, Imo State, Reproductive Health Service Law No. 3 of 2003, Rivers State.

47 Anyaleye Amuda Oluwakemi "Women and Reproductive Health Rights in Nigeria" Ontario Development Agency SSN 1923-6654.128 http:// www.ssrn.com/link/OIDA-Intl-Journal-Sustainable-Dev.html <accessed 31 October 2019>. 
Discriminatory customary practices in Nigeria, not only infringe on women's rights but also on other constitutionally provided rights. ${ }^{48}$ For instance, despite the existence of section 42(1) of the Constitution, which provides for freedom from discrimination, this is unarguably one of the major setbacks to the protection and enforcement of reproductive rights in Nigeria. The discrimination against women on the basis of their gender is still prevalent in many parts of Nigeria. Women are denied access to some platforms, which men have unfettered access to, there are also cases of unequal pay, and unequal working standards between men and women in organizations. ${ }^{49}$ This, in turn, leads to unequal access to resources, consequently poverty, suffering, health risks, and even death. Approximately 70 per cent of the population lives below the poverty line and the majority of them are women. Poor reproductive health and low standard of enforcement are associated with these developmental challenges. ${ }^{50}$

We also see prevalent customary practices in some parts of Nigeria, such as female genital mutilation, ill-treatment of widows, which are all detrimental to the woman's reproductive health and rights. Sadly, in spite of existing legislations, approximately 125 million women and girls worldwide have undergone FGM. ${ }^{51}$ Nigeria has about 27 per cent of girls and women aged 15 to 49 who have undergone FGM, and many more are still at risk. It is obvious that while legislation outlawing FGM is a vital element in its prevention, evidence that the legislation has had a deterrent effect in preventing FGM or accelerating its abandonment is limited. ${ }^{52}$ Any legislation that is not backed by robust monitoring and adequate mechanisms and institutions to enforce it within a communitybased support system is unlikely to be effective. In addition, enforcement

48 Ogugua Ikpeze "Customary Perspective on Reproductive Health Rights" (2014) 4-5 Journal of Health Law and Reproductive Rights (JHLRR) 60.

49 Damilola Olawuyi and Idowu Ajibade, "Climate Change Impacts on Housing and Property Rights in Nigeria and Panama: Toward a Rights-Based Approach to Adaptation and Mitigation", in: Dominic Stucker and Elena Lopez-Gunn (eds.) Adaptation to Climate Change through Water Resources Management: Capacity, Equity and Sustainability (New York: Routledge 2014) 264-284.

50 Supra note 42.

51 Female genital mutilation.

52 Jane Muthumbi, Joar Svanemyr, Elisa Scolaro, et al (2015) Female Genital Mutilation: A Literature Review of the Current Status of Legislation and Policies in 27 African Countries and Yemen. African Journal of Reproductive Health, September 2015: 19(3): 34. 
of laws without sufficient emphasis on raising awareness of the law may be problematic. ${ }^{53}$

The patriarchal nature of the Nigerian society is the bane of discrimination where women are believed to exist solely for the benefit of men. This explains why concepts like marital rape as described in the VAPP Act received a backlash from the male folk. The rejection of the Gender and Equal Opportunities Bill by the National Assembly is also a sad reflection of the dominant role of patriarchy and similar sentiments in Nigerian governance. Another factor negating this is the unavailability or limited access to good healthcare services in Nigeria. Statistics indicate a poor and deteriorating state of women's reproductive health status in the country. ${ }^{54}$ Suffice it to say that the problem of poor or even nonexistent healthcare services in the country contributes largely to the increased maternal mortality rate, which has remained one of the highest in the world. ${ }^{55}$ Reproductive health care is fundamental to women's wellbeing, thus attention must be given to women's health in Nigeria to prevent incessant deaths, disability and diseases related to pregnancy, improperly done abortions and childbirths. ${ }^{56}$ However, the need for women to have access to quality reproductive health services such as medical care, planned family, safe pregnancy, delivery care and treatment and prevention of sexually transmitted infections, such as HIV \& AIDS is slowly gaining recognition in Africa at large and Nigeria in particular. ${ }^{57}$

The dearth of specific laws on reproductive rights is another major impediment to promotion and protection of these rights. The provision in section 17 of the Nigerian Constitution ${ }^{58}$ is non-justiciable and, thus, unenforceable. Although the National Health Policy and Strategy, 1988, ${ }^{59}$ may be relevant, it is not supported by the existing laws, which have

53 Ibid.

54 Nkolika Ijeoma Aniekwu Reproductive Health Law; A Jurisprudential Analysis of Gender Specific Human Rights for the African Region 1st edn( Ambik Press Nigeria, 2011), p. 84.

55 Ibid.

56 Ibid.

57 Anyaleye Amuda Oluwakemi "Women and Reproductive Health Rights in Nigeria" Ontario Development Agency SSN 1923-6654.128 http:// www.ssrn.com/link/OIDA-Intl-Journal-Sustainable-Dev.html < accessed 31 October 2019>.

58 Which provides for adequate medical and health facilities for citizens.

59 The Federal Ministry of Health, National Policy and Strategy to achieve health for all Nigerians (1988). 
contrary provisions. It is reasonably clear that the existing legal framework is not only sparse, but is also fraught with delimiting provisions and is ill-equipped to serve as the foundation for the guarantee and enforcement of women's reproductive rights. ${ }^{60}$

Finally, the need for a structured institutional framework for the promotion and implementation of these rights cannot be overemphasized. The next section discusses some practical steps for reform.

\section{RECOMMENDATIONS FOR ADVANCING WOMEN'S REPRODUCTIVE RIGHTS IN NIGERIA}

A starting point for better protecting women's reproductive rights in Nigeria is to put in clear, comprehensive and bespoke legislation on women's reproductive rights. For example, the VAPP Act is a good step in this direction and more states will need to domesticate this law. However, its provisions mainly focus on violence issues and do not fully elaborate on all the aspects of women's reproductive rights.

This raises the need for specific legislation on reproductive rights in Nigeria. For example, in Victoria, Australia, there is the Infertility Treatment Act 1995, which itself was replaced by the Assisted Reproductive Treatment Act in 2008. This particular law is for the benefit of same sex marriage couples, yet it demonstrates consolidated efforts in countries that are interested in enforcement of women's reproductive rights. While some countries enact new gender-specific and sensitive laws, some others amend their existing laws to promote reproductive health and rights (for example, Slovakia incorporated the provisions of the European Commission on gender equality into its Anti-Discrimination Act of 2004, while Germany's wage transparency law and Iceland's equal pay law all make it illegal to pay unequal wages based on gender). This article emphasizes the need for specific legislations, that guarantee various aspects of reproductive rights. South African Constitution 1996, Ch. 2, s 12(2)(a) provides that "Everyone has the right to bodily and psychological integrity, which includes the right to make decisions concerning reproduction". Also, Ch. 2, s 27(1) (a) provides that "Everyone has the right to have access to health care services, including reproductive health care".

60 Supra note 48. 
Sole dependence on the courts for enforcement of women's reproductive rights has proven insufficient over the years. There is a need, therefore, for the enactment of specific reproductive health laws in Nigeria. These laws should have comprehensive provisions accompanied by strict penalties for default. Clear and specific provisions should be directed at safeguarding women's rights: prohibiting and penalizing sexual harassment, sexual assault, and gender-based violence. It will also be necessary to strengthen the institutional framework for enforcing these laws; it is the indispensable machinery needed after the right legislation has been put in place.

Secondly, the right to health, as provided in the Constitution, should be made justiciable, and enforceable. The implication of this is that provision of adequate and good healthcare facilities, which is paramount in the protection of the right to health, will become government's priority. Furthermore, to strengthen Nigeria's legal framework, International laws such as CEDAW, the Additional Protocol on Women's Right to the African Charter 2003 should be domesticated and implemented at the national level. Furthermore, the Nigerian Government should strengthen the National Health Policy Guidelines. The Ministry of Health, hospital management boards, etc., should be tasked with ensuring compliance with the National Health Policy goals, which include giving adequate health care to Nigerians. Hospital staff requires re-orientation, education and training on the intricacies of women's reproductive health and rights.

Thirdly, government agenda should include policies to promote education and awareness, especially in the rural areas. Seminars and workshops, rallies, talk shows and conferences must be encouraged and sponsored. Information on prevention of transmittable diseases such as HIV \& AIDS must be disseminated non-stop. Enlightenment on how to live with HIV \& AIDS by carriers is a necessary to eliminate the problem of stigma, discrimination as well as limit the spread of the disease by the carriers. Women empowerment programmes to eliminate poverty, which is a key element that fosters abuse of women's rights, should also be sponsored. Civil society groups and NGOs must also be proactive in their support for women. More lawyers should be encouraged to do pro-bono cases for women whose rights have been violated.

\section{CONCLUSION}

Reproductive health and rights are indispensable to societal development and progress. There are numerous examples from the developed world 
that Nigeria can imbibe in developing its own legal and institutional framework for protecting reproductive rights. For example, the American Association of University Women (AAUW) believes that every woman has the ability to make her own informed choices regarding her reproductive life within the dictates of her own moral and religious beliefs. Furthermore, AAUW posits that these deeply personal decisions should be made without government interference. AAUW members have made the protection of reproductive rights a policy principle since 1977. Family planning fosters self-sufficiency, promotes preventive health care, and educates people on ways to protect themselves and their families from the spread of sexually transmitted infections (STIs).

Even in developed countries where reproductive rights have been codified, we see that the clamour for full independence and freedom from governmental interference with reproductive rights is still ongoing, which shows the importance of this discourse to national development. Fostering and protection of reproductive rights as they affect women's health and freedom of choices, is unarguably a tool for national development. This article has identified two major areas that require serious reform in order to enhance the promotion of reproductive rights. These are the need for specific legislations on reproductive rights, and the need for a turn-around in the health care sector in Nigeria.

Providing sharper legislative protection for women's reproductive rights can provide women with limitless platforms to express themselves, while moving the unfettered protection of their rights from mere aspirations to reality. The place of activism cannot be overemphasized as this has been known to bring about changes in sexual orientation, ethnicity, race, and general behavioural patterns in many other countries of the world. More and more, Nigerian women are becoming increasingly aware of their reproductive rights and are clamouring for the enforcement of these rights. 